\title{
HUBUNGAN PENERAPAN DIET GLUTEI FREE \& CASEIN FREE (GFCF) DENGAN PERUBAHAN PERILAKU AUTIS DI SLSBN PEMBINA PEKANBARU
}

\author{
Yessi Azwar ${ }^{1,2}$, Novi Yanti ${ }^{1,2}$ \\ ${ }^{1}$ Program Studi D III Kebidanan, ${ }^{2}$ Stikes Payung Negeri Pekanbaru \\ Korespondensi Penulis: azwaryessi@gmail.com
}

\begin{abstract}
Abstrak
Latar Belakang dan tujuan: Kasus autisme didunia pada anak (autism Infntile) semakin banyak sehingga menimbulkan kekhawatiran dikalangan masyarakat terutama orang tua. Kasus autis di amerika serikat pada tahun 2016 diperkirakan terdapat 400.000 individu dengan autisme (Juwanto, 2016). Penulis mendapatkan data penyandang autis di Provinsi Riau khususnya Pekanbaru pada tahun 2015 diperkirakan sekitar 1.044 yang tersebar dibeberapa Kabupaten (DisdikRiau, 2017). Tujuan penelitian ini untuk mengetahui hubungan penerapan diet Glutein Free \& Casein Free (GFCF) dengan perubahan perilaku pada anak autis di SLBN Pembina Pekanbaru.

Metode: Jenis penelitian ini merupakan penelitian jenis kuantitatif, menggunakan desain korelasi dengan pendekatan cross sectional. sampel pada penelitian ini adalah 52 responden melakukan pengisian kuesioner keadaan sebelum diet dan setelah diet.

Hasil: Berdasarkan hasil uji statistic chi square diperoleh nilai $p=0.000$ dan nilai signifikan lebih kecil dari $\alpha 0.05(p=0.000<0.05)$.

Simpulan: Disimpulkan bahwa ada hubungan penerapan diet GFCF dengan perubahan perilaku pada anak autis.
\end{abstract}

Kata Kunci: Anak Autis, Diet Glutein Free \& Casein Free (GFCF), Perubahan Perilaku

\section{Pendahuluan}

Anak merupakan dambaan setiap keluarga. Setiap keluarga juga mengharapkan anaknya kelak tumbuh kembang optimal (sehat fisik, mental/kognitif, dan sosial), namun dewasa ini banyak terdapat gangguan dalam tumbuh kembang anak salah satunya autisme, istilah autisme pertama kali dikenalkan oleh Dr. Leo Kanner, seorang psikiatri dari universitasjohn Hopkins pada tahun1943 yang disebutnya sebagai autisme infatil (sotjiningsih dalam Sartika, 2015).

Tumbuh kembang merupakan proses yang berkesinambungan yang terjadi sejak konsepsi dan terus berlangsung sampai dewasa, dalam proses mencapai dewasa inilah anak harus melalui berbagai tahap tumbuh kembang. Tercapainya tumbuh kembang optimal tegantung pada potensi biologik, tingkat tercapainya potensi biologik seseorang merupakan hasil interaksi antara faktor genetik dan lingkungan bio-psiko- psikososial (Biologis, fisik dan psikososial) (Sartika, 2015).

Autis merupakan kelainan neorobiologikal yang berat yang terjadi sejak awal kehidupan anak yang sering terdiagnosis pada umur 18 sampai 30 bulan. Autis saat ini lebih dikenal dengan istilah autisme spectrum disorder (ASD) yaitu kumpulan dari beberapa gejala yang berdampak pada keterlambatan dalam pertumbuhan dan perkembangan yang muncul sebelum usia 3 tahun, dan anak mempunyai fungsi abnormal dalam tiga bidang yaitu interaksi sosial, komunikasi dan perilaku yang terbatas dan berulang (Sartika, 2015).

Kasus autisme didunia pada anak (autism infantile) semakin banyak sehingga menimbulkan kekhawatiran dikalangan masyarakat terutama orang tua. Prediksi penderita autis tahun ke tahun semakin meningkat. Kasus autis di Amerika Serikat 
pada tahun 2016 diperkirakan terdapat 400.000 individu dengan autisme (Juwanto, 2016) sedangkan di Indonesia hingga kini belum ada data resmi berapa jumlah penyandang autisme (Malikha, 2017). Penulis mendapatkan data pengandang autisme di Provinsi Riau khususnya Pekanbaru pada tahun 2015 diperkirakan sekitar 1.044 yang tersebar dibeberapa kabupaten (DisdikRiau, 2017).

Gejala autis meliputi gangguan komunikasi, interaksi sosial dan perilaku. Gejala autis bisa terlihat ketika anak memasuki usia 1-3 tahun. Gejala ini berdampak pada keterlambatan perkembangan dan pertumbuhan terutama pada bahasa untuk berkomunikasi dengan orang lain. Autis cenderung mengulang katakata dan mengalami kesulitan untuk memulai pembicaraan sehingga lebih memilih diam dan sibuk dengan kegiatannya sendiri. Anak autis mengalami kerusakan hubungan sosial, terkadang menarik diri dari lingungannya (Andayani, 2016).

Masalah dan gejala anak autis sangat diperlukan peran dari beberapa tenaga ahli seperti: ahli saraf, ahli perkembangan anak, psikologi, ahli gizi, ahli bicara, orang tua, konsultan atau profesional lainnya yang mempunyai pengetahuan mengenai anak autis. Anak autis biasanya memiliki kebiasaan makan yang berbeda, seperti sering memakan jenis makanan yang sama secara berulang-ulang dalam waktu yang cukup lama. Anak autis juga mengkonsumsi makanan yang relatif terbatas. Kebiasaan makan pada anak autis dapat berpengaruh pada perbaikan perilakunya (Onibala, dkk, 2016).

Peran orang tua sangat diperlukan dalam menerapkan terapi Diet, karena orang tua merupakan orang yang paling dapat mengerti dan dimengerti oleh anak penyandang autis. Orang tua harus bisa memperkaya pengetahuannya seputar tentang autis, terutama dalam hal terapi yang tepat dan sesuai dengan anak (Prasetyono,2008). Orang tua merupakan salah satu faktor yang sangat berpengaruh terhadap penerapan diet bebas gluten dan bebas casein pada anak, karena pola makan pada anak autis tidak terlepas dari peran seorang ibu dalam menyediakan makanan yang baik, bergizi dan sesuai dengan kebutuhan anaknya (Marlina,2015).

Metode penyembuhan untuk anak autis terdapat berbagai jenis terapi telah dilakukan untuk mengembangkan kemampuan anak autis sehingga anak dapat hidup normal. Terapi yang dilakukan secara intensif dapat menghilangkan gejala- gejala autis sehingga anak bisa bergaul secara normal. Gejala pada anak autis jika terlambat mendapatkan intervensi hingga dewasa, maka gejala autis bisa menjadi semakin parah, bahkan tidak tertanggulangi. Terapi yang rutin pada anak autis akan mengalami kemajuan seperti anak normal lainnya (Danuatmaja, 2003). Salah satu jenis terapi untuk anak autisme adalah melalui makanan atau di sebut terapi diet. Dari beberapa jenis diet untuk anak autis, diet yang umum dilakukan adalah Diet Gluten Free Casein Free (GFCF). Pada umumnya orang tua mulai dengan diet tanpa gluten dan kasein, yang berarti menghindari makanan dan minuman yang mengandung gluten dan kasein (Sofia, 2012).

Menurut Purwanto (2006) terdapat beberapa faktor yang mempengaruhi kepatuhan orang tua dalam menerapkan terapi diet bebas gluten dan bebas casein pada anak autis, diantranya: faktor demografi, pengetahuan, komunikasi terapeutik, sikap, dan dukungan keluarga (Purwanto, 2006). Rendahnya keterlibatan orang-orang di rumah dalam penerapan diet, seperti anggota keluarga bebas memberikan makanan pada anak yang mengakibatkan anak akan sering melihat dan terbiasa dengan kebiasaan-kebiasaan buruk tersebut pada penerapan diet yang dijalaninya (Sofia 2011 dalam Andayani 2016).

Menurut Washnieski (2009), ada beberapa rintangan / hambatan dalam upaya menerapkan diet GFCF diantaranya ada perlawanan dari anak, pembatasan diet yang membuat anak sulit untuk makan, masalah lingkungan sekolah, orang tua tidak tahu bagaimana menyiapkan makanan yang bebas kasein dan gluten, tidak tahu dimana harus menemukan sumber yang dapat membantu 
untuk mengimplementasikan diet, dsb. Halhal tersebut dapat menjadi salah satu faktor yang tidak mendukung orang tua dalam menerapkan diet CFGF (Sofia, 2012).

Dari beberapa kasus autis didalam Budhiman (2008), bahwa pada umumnya orang tua yang melaksanakan terapi diet mengalami kesulitan dalam melakukan penerapan diet misalnya mengalami kesulitan keuangan untuk pengobatan anak autis yang membutuhkan biaya cukup banyak, tingkat ekonomi merupakan kemampuan finansial untuk memenuhi segala kebutuhan hidup (Budhiman, 2008).

Menurut hasil penelitian Hartiningrum (2012), setelah dilakukan penerapan terapi diet GFCF secara umum terjadi perbaikan pola perilaku dengan perbandingan rata-rata total skor 124,94 sebelum dilakukan penerapan diet dan setelah dilakukan penerapan diet GFCF skor menjadi 54,56. Pola perilaku yang mengalami perbaikan terbanyak yaitu pada aspek anak dapat mengerti penjelasan dan menuruti perintah sebanyak 61,1\% (Hartiningrum,2012).

Berdasarkan hasil wawancara yang dilakukan penulis di SLBN Pembina Pekanbaru yang beralamat di jalan Segar dan terdapat 395 siswa dari kelas I-XII, dari total keseluruhan siswa terdapat 37 siswa penyandang autis. Berdasarkan hasil observasi dan wawancara dimana pada 5 orang tua siswa terdapat 3 anak membawa bekal makanan sendiri dari rumah dan 2 anak lainnya membeli jajanan disekolah. Penulis mendapatkan 4 orang tua yang menerapkan makanan dengan diet GFCF untuk anaknya disekolah tetapi belum menerapkan secara teratur dan 1 orang tua yang belum menerapkan terapi GFCF. Berdasarkan penjelasan diatas maka penulis tertarik untuk melakukan penelitian yaitu : "Pengaruh Penerapan Terapi Diet Glutein Free \& Casein Free (GFCF) Terhadap Perubahan Perilaku Anak Autis Di SLBN Pembina Pekanbaru".

\section{Metode Penelitian}

Penelitian ini merupakan penelitian kuantitatif dengan menggunakan desain penelitian korelasi menggunkan pendekatan cross sectional (Sugiyono, (2009) yaitu melihat atau meneliti dalam waktu yang bersamaan, tentang pengaruh penerapan terapi diet dengan perubahan perilaku pada anak autis di SLBN Pembina Pekanbaru. Lokasi penelitian ini dilakukan di SLBN PEMBINA Pekanbaru, karena berdasarkan data yang didapatkan dari Dinas Pendidikan tahun 2017 bahwa SLBN Pembina memiliki siswa terbanyak di kota Pekanbaru di antara SLB lainnya yang ada di kota Pekanbaru. Tehnik pengambilan sampel menggunakan total populasi, artinya peneliti akan meneliti keseluruhan siswa yang sedang bersekolah di SLBN Pembina dengan status Penyandang autis berjumlah 52 orang dengan kriteria telah melakukan diet GFCF.

\section{Hasil dan Pembahasan}

\section{a. Analisis univariat}

Analisis univariat adalah analisis yang digunakan untuk mendapatkan data mengenai karakteristik responden meliputi, jenis kelamin, umur, umur saat didiagnosa, pekerjaan Ibu, pendidikan Ibu, pkerjaan Ayah, Pendidikan Ayah dan penerapan diet GFCF. Hasil analisis univariat yang diprleh pada penelitian ini adalah sebagai berikut:

Tabel 1 Karakteristik Responden berdasarkan Jenis Kelamin

\begin{tabular}{llcc}
\hline No & \multicolumn{1}{c}{ Jenis Kelamin } & Frekuensi & Persentasi (\%) \\
\hline 1 & Laki-laki & 39 & 75 \\
2 & Perempuan & 13 & 25 \\
\hline & Jumlah & 52 & $100 \%$
\end{tabular}

Sumber : Analisis Data Primer Tahun 2018 
Tabel 2 Karakteristik Responden berdasarkan Umur

\begin{tabular}{llcc}
\hline No & \multicolumn{1}{c}{ Umur (Tahun) } & Frekuensi & Persentase (\%) \\
\hline 1 & 0-5 Tahun & 1 & $1,9 \%$ \\
2 & 6-11 Tahun & 10 & $19,2 \%$ \\
3 & 12-16 Tahun & 23 & $44,2 \%$ \\
4 & 17-25 Tahun & 18 & $34,6 \%$ \\
\hline & Jumlah & 52 & $100 \%$ \\
\hline
\end{tabular}

Sumber : Analisis Data Primer Tahun 2018

Tabel 3 Karakteristik Responden berdasarkan Umur Saat Terdiagnosa

\begin{tabular}{llcc}
\hline No & Umur Saat Terdiagnosa & Frekuensi & Persentase (\%) \\
\hline 1 & 0-5 Tahun & 51 & $98,1 \%$ \\
2 & 6-11 Tahun & 1 & $1,9 \%$ \\
\hline & Jumlah & 52 & $100 \%$ \\
\hline
\end{tabular}

Sumber : Analisis Data Primer Tahun 2018

Tabel 4 Karakteristik Responden berdasarkan Pekerjaan Ibu

\begin{tabular}{llcc}
\hline No & \multicolumn{1}{c}{ Pekerjaan Ibu } & Frekuensi & Persentase (\%) \\
\hline 1 & IRT & 45 & $86,5 \%$ \\
2 & Karyawan Swasta & 5 & $9,6 \%$ \\
3 & Wiraswasta & 2 & $3,8 \%$ \\
\hline & Jumlah & 52 & $100 \%$ \\
\hline
\end{tabular}

Sumber : Analisis Data Primer Tahun 2018

Tabel 5 Karakteristik Responden berdasarkan Pendidikan Ibu

\begin{tabular}{clcc}
\hline No & Pendidikan Ibu & Frekuensi & Persentase (\%) \\
\hline 1 & D 3 & 4 & 7,7 \\
2 & S1 & 6 & 11,5 \\
3 & SMA & 37 & 71,2 \\
4 & SMP & 5 & 9,6 \\
\hline & Jumlah & 52 & 100 \\
\hline
\end{tabular}

Sumber : Analisis Data Primer Tahun 2018

Tabel 6 Karakteristik Responden berdasarkan Pendidikan Ayah

\begin{tabular}{llcc}
\hline No & Pendidikan Ayah & Frekuensi & Persentase(\%) \\
\hline 1 & D3 & 7 & 13,5 \\
2 & S1 & 15 & 28,8 \\
3 & SMA & 27 & 51,9 \\
4 & SMP & 3 & 5,8 \\
\hline & Jumlah & 52 & 100 \\
\hline
\end{tabular}

Sumber : Analisis Data Primer Tahun 2018

Tabel 7 Karakteristik Responden berdasarkan Diet GFCF

\begin{tabular}{llcc}
\hline No & Diet GFCF & Frekeunsi & Persentase (\%) \\
\hline 1 & Menerapkan & 37 & 71,2 \\
2 & Tidak Menerapkan & 15 & 28,8 \\
\hline & Jumlah & 52 & 100 \\
\hline
\end{tabular}

Sumber : Analisis Data Primer Tahun 2018 
Tabel 8 Karakteristik Responden berdasarkan Kategori Perilaku

\begin{tabular}{llll}
\hline No & Kategori Perilaku & $\mathbf{N}$ & $(\boldsymbol{\%})$ \\
\hline 1 & Berubah & 32 & 61,5 \\
2 & Tidak Berubah/Tetap & 20 & 38,5 \\
\hline & Jumlah & 52 & 100 \\
\hline
\end{tabular}

Sumber : Analisis Data Primer Tahun 2018

Tabel 9. Hubungan Penerapan Diet Glutein Free dan Casein Free (GFCF) Dengan Perubahan Perilaku Pada Anak Autis

\begin{tabular}{|c|c|c|c|c|c|c|c|c|c|}
\hline \multirow{3}{*}{ No } & \multirow{3}{*}{ Diet GFCF } & \multicolumn{6}{|c|}{ Kategori Perilaku } & \multirow{3}{*}{$\begin{array}{c}P \\
\text { value }\end{array}$} & \multirow{3}{*}{ OR } \\
\hline & & \multicolumn{2}{|c|}{ Berubah } & \multicolumn{2}{|c|}{$\begin{array}{c}\text { Tidak Berubah/ } \\
\text { Tetap }\end{array}$} & \multicolumn{2}{|c|}{ Jumlah } & & \\
\hline & & $\mathrm{N}$ & $\%$ & $\mathrm{~N}$ & $\%$ & $\mathrm{~N}$ & $\%$ & & \\
\hline 1 & Menerapkan & 29 & 78,4 & 8 & 21,6 & 37 & 100 & & \\
\hline 2 & $\begin{array}{c}\text { Tidak } \\
\text { Menerapkan }\end{array}$ & 3 & 20 & 12 & 80 & 15 & 100 & 0,000 & $(3.275-$ \\
\hline & Jumlah & 32 & 61,5 & 20 & 38,5 & 52 & 100 & & \\
\hline
\end{tabular}

\section{Pembahasan}

Berdasarkan hasil analisa hubungan diet GFCF dengan perilaku diperoleh 29 $(78,4 \%)$ responden perilaku berubah dengan menerapkan diet GFCF, sementara $12(80 \%)$ responden dengan perilaku tidak berubah/tetap dengan tidakMenerapkan diet. Hasil uji statistic chi square diperoleh nilai $\mathrm{p}=0.000$ dan nilai signifikan lebih kecil dari $\alpha 5 \%(\mathrm{p}=0.000<0.05)$ maka Ho ditolak dan Ha gagal ditolak dapat disimpulkan bahwa ada hubungan penerapan diet GFCF dengan perubahan perilaku pada anak autis. Penelitian ini sejalan dengan penelitian yang dilakukan oleh Hastuti (2014) bahwa dari 10 orang tua yang patuh menerapkan diet bebas gluten dan kasein 6 anak $(28,6 \%)$ mengalami perubahan perilaku dengan hasil analisis data uji statistik Spearman Rho Correlation didapatkan $p=0,000$.

Penerapan diet bebas gluten dan bebas kasein dipengaruhi oleh faktor internal dan eksternal. Faktor internal berasal dari dalamdiri anak autis maupun ibu sendiri, sedangkan faktor eksternal yang akan mendukung penerapan diet secara konsisten berasal dari lingkungan sekitar termasuk orang-orang disekitarnya. Peran ibu sangat dibutuhkan dalam pengawasan pola makan anak (Kessick, 2009). Berdasarkan hasil penelitian dapt dilihat dari penerapan orang tua terhadap diet bebas glutein dan kasein. Anak yang mengalami perubahan perilaku autis pada umumnya orang tua yang menerapkan diet bebas gluten dan kasein, sebaliknya perilaku autis tidak mengalami perubahan/ tetap pada orang tua yang tidak menerapkan diet.

Menurut Nugraheni (2009) semakin tingginya konsumsi bahan makanan yang mengandung gluten dan casein maka akan semakin seringnya perilaku autis. Perilaku autis disebabkan oleh tidak sempurnanya proses pemecahan protein yang terkandung dalam glutein dan casein. Glutein dan casein merupakan bagian dari asam amino rantai pendek yang biasa disebut peptida. Keadaan normal peptida hanya diabsorbsi sedikit oleh tubuhdan sebagian besar lagi dibuang melalui feses namun tidak demikian pada penderita autis.

Hipermeabilitas pada mukosa usus penderita autis menyebebakan peptida ini meningkat, sebagian peptida diabsorbsi masuk ke sirkulasi alirn darah dan sebagian lagi peptida tersebut menuju otak. Peptida yang menuju ke otak menempel pada reseptor opioid diotak dan berubah fungsi seperti morfin. Peptida gluten akan membentuk glutemorphin atau gliadimorphin dan peptida casein akan membentuk caseomorphin, kedua zat tersebut dapat mempengaruhi system saraf 
pusat sehingga dapat menimbulkan gangguan perilaku (Apriani, 2016). Pernyataan tersebut sesuai dengan hasil yang telah dilakukan pada penelitian ini, bahwa penderita autis yang memiliki kebiasaan frekuensi rendah dalam mengkonsumsi makanan gluten maupun kasein terjadi perubahan perilaku yang lebih terarah dibandingkan mereka yang memiliki frekuensi yang tinggi dalam konsumsi makanannya.

Menurut asumsi peneliti semakin sering orang tua menerapkan diet gluten dan casein pada anak maka hasil yang diperoleh pun semakin maksimal dimana perilaku anak akan mengalami berubahan menjadi lebih baik. Dalam penerapan diet tentu peran orang tua dan orang sekitar lingkungan harus saling mendukung anak untuk menerapkan diet GFCF.

\section{Simpulan}

Hasil penelitian telah dilakukan tentang "Hubungan Penerapan Diet Glutein Free \& Casein Free (GFCF) Dengan Perubahan Perilaku Pada Anak Autis Di SLB Negeri Pembina Pekanbaru"

a. Mayoritas diet GFCF yang menerapkan sebanyak $37 \quad(71,2 \%)$ responden sementara $15(28,8 \%)$ responden yang tidak menerapkan diet GFCF.

b. Mayoritas perilaku responden berubah sebanyak $32(61,5 \%)$ sementara 20 $(38,5 \%)$ respon perilaku tidak berubah / tetap.

c. Berdasarkan hasil uji statistic chi square diperoleh nilai $p=0.000$ dan nilai signifikan lebih kecil dari 5\% ( $p=0.000$ $<0.05)$ maka Ho ditolak dan Ha gagal ditolak dapat disimpulkan bahwa ada hubungan penerapan diet Glutein Free \& Casein Free (GFCF) dengan perubahan perilaku pada anak autis.

\section{Referensi}

Andayani, 2016. Pola Konsumsi Makanan, Status Gizi Dan Perilaku Anak Autis. Program Studi SI Pendidikan Tata Boga Fakultas Tehnik Universitas Negeri Surabaya. Jurnal Boga, Vol.5,
No 3. Halaman 48-53, diakses Pada Oktober 2017.

Asri, A. (2017). Perilaku anak autis. Akses pada bulan Januari 2018 di www.kompasiana.com

Apriani. (2016). Pengaruh Diet Gluten Free Dan Casein Free Terhadap Perilaku AutisDi Makassar. Akses pada bulan Desember 2017

Barmien. (2014). Terapi Diet Untuk Anak autis. Diakses pada Desember 2017 di WordPress.com

Budhiman. (2008). Cahaya Ananda Pusat Terapi. Akses pada bulan Desember 2017 di blogspot.co.id

DisDik, Riau. (2017). Disdik Riau Luncurkan Program Rumah autis. Akses pada bulan Desember 2017 di www.AntaraRiau.com.

Jee-seon Shim, dkk. (2014). Dietary assesment methods in Epidemiologic Studic. Epidemiology And Health Cross Merk. Jurnal Vol:39 No. 2

Juwanto,Dr. (2016). Pediatrician Clinical and Editor Inchif. Akses pada bulan Desember $2017 \quad$ di www.KinikAutis.com

Indra, Kumang. (2014). Hubungan Kebiasaan Makan makanan Cepat Saji, aktifitas Fisik dan Pengetahuan Gizi dengan Status Gizi pada Mahasiswa FK UNILA Bandar Lampung. Program Sarjana Kedokteran Universitas Lampung.

Kessick, R. (2009). Autisme dan Pola Makan Yang Penting Untuk Anda Ketahui. Penerjemah Savitri. Jakarta : Gramedia Pustaka Utama

Khatimah, (2015). Glutin Free Casein FreeDit Kasin Dan Gluten Untuk Anak Berkebutuhan Khusus. Diakses pada desember 2017 dari www.slideshare.net

Kusuma, K. D. (2011). Metode Penelitian Keperawatan. Jakarta:Trans Info Media

Hidayat, A.A.A. (2007). Metode Penelitian Keperawatan dan Tehnik Analisa Data. Jakarta : Salemba Medika 
e-ISSN : 2614-5685

p-ISSN : 2614-5421

Malikha. (2017). Menanti Autis Center Riau. Akses pada bulan desembe 2017 di RiauPos.co 